\title{
Training needs of general library workers: Part I (challenges facing educators in South African institutions of higher learning)
}

\author{
Hester W.J. Meyer' \\ University of South Africa, Department of Information Science \\ meyerhwj@unisa.ac.za
}

Received: 10 February 2010

Accepted: 3 July 2010

\begin{abstract}
A recent survey by Meyer [2009) on the need for the training of general library workers revealed that employers in library services are often not aware of the conditions affecting the ability of library and information science [IIS) educators at South African tertiary institutions to deliver 'work ready' general workers to the LIS industry. Simultaneously, LIS educators are not aware of the extent to which changes to learning programmes can affect the appointment and promotions of library staff in practice. The objectives of the study were to determine the need for a formal learning programme for general library workers and how existing study material can be adapted to develop a formal learning programme suitable for general library workers countrywide. Data was collected by means of a self-administered questionnaire directed at supervisory staff of provincial and municipal libraries in South Africa, interviews with supervisors, and consultation of relevant internal documentation on job descriptions and legislation. The findings revealed that there is a definite need for training general library workers, whether formally or informally.

This article, the first of two parts, considers the challenges facing LIS educators of which employers in the LIS industry are seldom aware of. The discussion is based on a literature study regarding training of general library workers in South Africa, as well as personal experience of the impact of various conditions on the relevant learning programmes of the Department of Information Science, University of South Africa before and after merging with the former Technikon SA. It considers the implementation of legislation and policies with regard to LIS training and how LIS educators, involved in open distance learning $(\mathrm{DDL}$ ) cope with the specific challenges for delivering 'work ready' general library workers. Part two will deal with aspects concerning the types of task general workers perform, and the specific type of training required to ensure that these workers contribute to efficient service delivery.
\end{abstract}

Keywords: General library workers; training needs; library and information science; tertiary learning institutions, South Africa

\section{Introduction}

The smooth flow of daily operations in a library depends to a large extent on the competencies of its general library workers, who perform routine tasks that vary between administrative, technical tasks and sometimes more professional tasks. To be appointed as a general library worker, the prospective candidates need to demonstrate proficiency in the critical cross[field skills of reading, writing and numeracy expected of school leavers at Grade 12, or equivalent (Department of Education 2007). However, in South Africa support staff in public libraries often include personnel with professional qualifications at a diploma level, and even with a bachelor's degree other than the professional bachelor's degree in Library and Information Science (Meyer 2009). Workers with the latter two types of qualification are better known as paraprofessionals and often perform tasks of a professional nature.

Traditionally, libraries used to provide in \$service training to their general library workers as the need arose. However, as conditions and demands within the library environment have changed, library services depend increasingly on learning institutions to offer a variety of learning programmes that will deliver a 'work ready' workforce. Academic departments at tertiary learning institutions in South Africa thus face the challenge of offering qualifications that satisfy the needs of the job market and simultaneously comply with the requirements of the Higher Education Qualifications Framework (HEQF), as constituted by the Higher Education Act $10 \mathrm{I}$ of 1997 (Department of Education 2007). In addition learning institutions that offer tertiary qualifications are bound by the stipulations of the Higher Education Management Information System (HEMIS) of the respective institution with regard to the cost of offering a particular qualification, which requires a minimum number of students per cost unit. Simultaneously learning institutions strive to comply with the demands of a job market that requires a workforce with the necessary knowledge, competence and skills to allow service providers to remain at the forefront of service delivery. Continuing technological advances and the emergence of a new and diverse group of jobseekers require training in not only basic but also new skills and the necessary know thow

I. Hester WJ Meyer $(\mathrm{PhD})$ is an associate professor in the Department of Information Science at the University of South Africa, Preto $\square$ ria. 
to offer the relevant services. Naturally these will have a bearing on the composition of a learning programme for general library workers.

Amendments to the Higher Education Act 101 of 1997, advances in information and communication technologies (ICTs), as well as staff allocations in the library and information services (LIS) environment posed challenges for curriculum development aimed at offering appropriate qualifications for general library workers.

With regard to the LIS profession, general library workers form a part of the workforce assigned to routine tasks varying from issuing books, registering members, answering enquiries, keeping statistics of library use, shelving, stocktaking, etc. (Meyer 2009). Their training needs are of particular interest to LIS educators at tertiary learning institutions, since their post levels require only the successful completion of Grade 12 (or an equivalent) and the basic reading, writing and numeracy skills required at that level. However, general library workers are working in a context where background knowledge of the LIS profession and basic skills for organising and retrieving information and information sources (i.e. indexing, classification, filing, etc) are taken for granted. This implies that competencies beyond only the cross critical skills efficiency required for completion of Grade 12 are required. The problem that arises is that the type of routine tasks typical of the functions of a library service do not require only training ${ }^{2}-$ in the sense of coaching - but also learning - in the sense of gaining knowledge and competence within the disciplinary context of LIS. However, hands on training seems to be the crucial component that will ensure the correct application of routine procedures.

Considering the nature of the tasks that general library workers need to perform and the requirements for learning programmes as stipulated by the HEQF, the core problem for LIS educators revolves around the challenge of offering learning programmes that comply with the requirements of both the LIS industry and the HEQF. In addition to the core problem arises the problem of disparity in terms of (a) requirements to be appointed as a general library worker (critical cross field skills mentioned above) and (b) entry level requirements (university exemption) for formal learning programmes offered at institutions of higher learning subsidised by South Africa's national Department of Higher Education and Training (DHET).

The purpose of this article is to reflect on the challenges facing LIS training as affected by legislation - more specifically the training of general library workers as experienced by the Department of Information Science at the University of South Africa (Unisa). This article is the first of two dealing with the training needs of general library workers and will focus specifically on the challenges faced by LIS educators to deliver 'work ready' candidates to the LIS industry.

\section{Background}

In order to put the problem regarding LIS training at Unisa into perspective, it is necessary to provide background on the following core aspects of the problem, namely (a) the need for training of general library workers to become work ready, (b) legislation with regard to higher education and how it manifests itself in programmes at tertiary learning institutions,

(c) LIS curricula at distance learning institutions and (d) the need for rationalisation to adapt to changes that have occurred over time.

\subsection{Need for training of general library workers}

General library workers, also known as support staff, form part of the workforce of libraries. According to their job descriptions support staff perform routine library tasks within the sections where they are deployed (City of Johannesburg 2008, Ekurhuleni Metropolitan Library Services 2008, Tshwane Community libraries 2008). The nature of their work does not necessarily require formal ${ }^{3}$ training, but rather hands $b n$ training in task \$pecific activities.

Traditionally general library workers received in/\$ervice training in library\$pecific tasks irrespective of their academic qualifications. Such in \$ervice training is usually handled by senior staff members in accordance with the specific requirements of the library service. However, according to concerns raised by senior library staff in an official capacity (Van Aswegen 2006 ; Brown 2007; Pretorius 2007), as well as from public platforms such as the radio talk programme 'Praat saam' (RSG 2008), there seems to be a need for more structured training of library workers to be better prepared for their tasks upon appointment. From the survey conducted by Meyer (2009), it also seems that the professional staff in public libraries are under increasing pressure and senior staff members (depending on the staff capacity of individual libraries) no longer have the capacity to allocate staff to in \$ervice training initiatives.

2. For purposes of this article the term training is used in instances where aspects regarding hands bn experience in programmes for general library workers are implicated. The term learning is used with reference to programmes with a focus on gaining knowledge and competence.

3. Formal training here refers to programmes offered by tertiary institutions subsidised by government and complying with South Afri! can Quality Assurance (SAQA) criteria in Library and Information Science. Non_ormal training refers to programmes offered by ter $\square$ tiary institutions but which are not necessarily subsidised by government.

SA JnI Libs \& Info Sci 2010, 76(I) 
Librarians who phoned in to the radio talk show 'Praat saam' (RSG 2008) discussing the current position of library and information services in South Africa repeatedly raised library staff appointments under the jurisdiction of local municipalities as a cause of concern. Conditions related to the budget allocation for recruitment of trained library staff have apparently led to shortages of professional staff in most public libraries. Numerous cases were mentioned in which the appointment of only paraprofessional staff could be afforded. These circumstances put additional pressure on senior staff to allocate professional staff and time to train newly appointed staff in the use of the internet and other information technologies. The latter are prerequisites for the smooth operation of everyday LIS activities.

Many of the librarians who participated in the RSG talk programme also raised the concern that newly appointed staff members (both general and professionally qualified staff) have no understanding of the purpose of bibliographic control in the organisation and retrieval of library collections. In addition, a trend was observed among newly appointed support staff showing very little understanding of the very basic principles of alphabetic or numeric arrangement of library material, or filing and indexing of key terms. These are basic techniques that are used in everyday life to classify or group abstract concepts or physical objects, such as books; they are also critical cross[ield outcome skills one assumes to be in place when a candidate has passed Grade 12. Language proficiency in English seems to be another hurdle that prevents library management from fully deploying a newly appointed library staff member. These concerns also emerged from the survey regarding the need for training of general library workers (Meyer 2009).

Historically the LIS sector in South Africa seems to have been governed by legislation (Musiker 1986, DAC 2007, DAC 2010, Ocholla \& Bothma 2007), with provincial and public library services having been closely linked. Ordinances in the different provinces of South Africa were promulgated to set up provincial library services. These services, together with municipalities or smaller local government structures, were jointly responsible for providing public libraries in towns and villages "where there was already a reading population" (Musiker 1986:I7I). In this regard it is important to note that the municipality provided the site and the staff to run the library, which was in turn affiliated to the provincial library services that provided books and other stock (Dominy 2003:40).

Restructuring of provinces in 1996 brought confusion owing to the current Constitution (Act no. 108 of 1996) excluding library services from the list of powers and duties of municipalities (DAC 2007: 10). This oversight in Part A Schedule 5 of the Constitution resulted in these services deteriorating to unacceptable levels. In 2007 the national government announced the Community Services Grant (also known as Conditional Grant), which pledged RI billion over three years to develop infrastructure and stocks of books in local libraries (DAC 2007). The position of library services is poised to change as reflected in the South African Community Library and Information Services Bill (2010). According to the latter, provincial library services will in future be responsible for, among others, development of legislation, policy formulation, planning and coordination, and establishment, maintenance and capacity building of provincial and community libraries. The responsibilities of municipal libraries will involve establishing and maintaining community library services, managing and implementing allocated funds, appointing professional staff and providing and maintaining the infrastructure and equipment for the relevant library services.

Owing to uncertainties caused by earlier policies, as well as their direct impact on appointments of paraprofessional staff in public and related libraries, the concerns raised by public librarians relating to assigning roles to the respective services seem understandable. In addition, during the restructuring of the higher education sector in South Africa, 36 higher education institutions merged into 23 between 2000 and 2006 (DAC 2010:xx). The distinction between universities and universities of technology became blurred and a new type of comprehensive university emerged. Most of the former technikons, which used to offer vocational training in their library and information studies programmes, merged either with other institutions to become universities of technology or with universities. For example, the merger between the former Technikon SA and Unisa resulted in Unisa becoming one of the comprehensive universities. The void left by phasing out technikon certificate courses (offered as exit levels of the National Diploma in Library and Information Studies (NDLIS) programmes) could not be filled by any of the formal qualifications offered at universities. Unlike technikon training programmes, a library diploma offered at university level focuses more on the theory and functions of librarianship than on training in library tasks.

Currently public and related libraries seem to depend on individuals or library associations (e.g. LIASA) and tertiary institutions to offer workshops from time to time to introduce unqualified library workers to libraryßpecific tasks such as cataloguing and classification, indexing, internet searching, reference work, IT instruction and collection development. In this regard, LIASA announced a series of workshops, training camps and pre[konference workshops (LIASA 2008). However, these arrangements have disadvantages for both the tertiary institutions and the public libraries: in the case of universities, academics find it not only difficult to repackage course material of learning programmes for professionals at short notice but also time konsuming to scale down the contents to a level comprehensible to a lay person. Paraprofessionals undergoing training often expect to be awarded a certificate for training from a reputable institution 
that can guarantee future promotions, which is not possible with certificates for attending workshops. In addition, once $\square$ off exposure to knowledge and skills through workshops is not lasting and library services therefore do not seem to benefit from these workshops in the long run. Furthermore, according to personal viewpoints obtained through the survey (Meyer 2009), it seems that experience gained from attending workshops has a low weighting when it comes to promotion of staff or when candidates apply for a position in a library at another institution.

\subsection{Legislation and its implications for LIS educators}

To understand the extent to which qualifications offered by tertiary learning institutions can meet the needs of the LIS industry, it is necessary to understand the legislation that sets criteria for higher education in South Africa, as well as their implications. For purposes of this article the discussion on LIS education will primarily focus on learning opportunities for library support staff such as general library workers.

All tertiary learning institutions in South Africa that wish to register formal learning programmes need to comply with the required accreditation criteria of SAQA in order to be subsidised by the Department of Education. The HEQF as constituted by the Higher Education Act I0I of 1997 (South Africa, Department of Education 2007) set criteria that reflect quality assurance assigned to the different learning programmes as indicated in figure $\mathrm{I}$.

The different National Qualifications Framework (NQF) levels of the training programmes depicted in Figure I range from NQF level 5 for a higher certificate to NQF level 10 for a doctorate. The different NQF levels in Figure I indicate the level of complexity of the content of the learning programme (e.g. certificate, diploma, degree, etc.) to which it is assigned. The level of complexity increases with each successive learning programme as depicted in figure I.

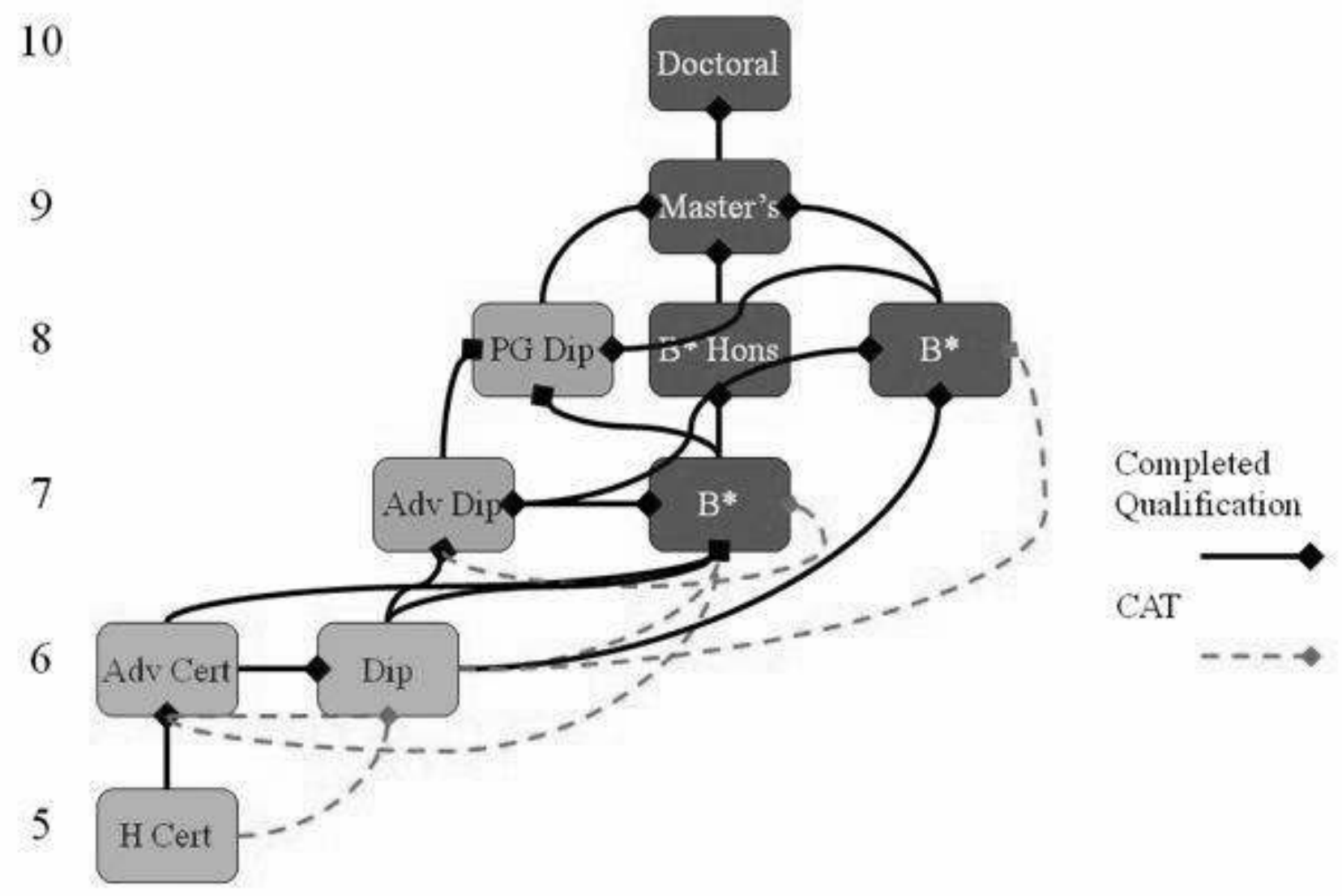

Figure 1 Depiction of HEQF formal learning programmes (reproduced with permission from Havenga 2007)

\subsection{Vocational training}

Library work depends heavily on real[life applications of knowledge and skills of information science. It is therefore understandable why such prominence is given to skills development in the literature on LIS education worldwide (Gerolimos 2009; Luo 2007; Ashcroft 2004; Fisher 2004; BlanksonßHermans \& Hibberd 2004; Middleton 2003; Biddiscombe 200I). An in depth study of the job descriptions of general workers in public and related libraries showed that most of the activities performed by general library workers are primarily task trelated (Meyer 2009). Considering the 
nature of their work, it seems only natural that learning programmes for general library workers should be work based (Van Rensburg 2008:5; Gerolimos 2009:531; Minishi[Majanja 2009).

Figure I shows that the HEQF makes provision for different levels of learning programmes. That is, both vocational and professional learning programmes. LIS schools in South Africa offer a number of formal LIS qualifications, including three levels of undergraduate programmes and four levels of postgraduate programmes (Minishi[Majanja \& Ocholla 2004). Of interest to the training needs of general library workers are the levels of undergraduate programmes, including certificates, diplomas and bachelor's degrees.

Considering the need for hands $[$ n training of general library workers, the HEQF as constituted by the Higher Education Act I0I of 1997 (Department of Education 2007) makes provision for vocational training (also known as work $\square$ integrated learning (WIL)) through the Higher Certificate and Advanced Certificate programmes, which have strong vocational components. Although the Higher Certificate and Advanced Certificate programmes do not require university exemption as admission requirements, the HEQF provides an access route to successful candidates to advance to a higher qualification. The broken lines between the Higher Certificate, the Advanced Certificate and Diploma in figure I clearly show the access route to a higher qualification. For a person without university exemption the route may be slightly longer, but the candidate could eventually advance to the highest level. The route is longer because the credit accumulation and transfer (CAT) rule (indicated in Figure I) stipulates that a student may not transfer more than $50 \%$ of the credits of a completed qualification (Minishi[Majanja 2009).

The HEQF makes provision primarily for formal learning programmes that are accredited with the Council of Higher Education (CHE) according to SAQA standards, which means its qualifications are subsidised by DHET.

Apart from the formal training discussed above, tertiary institutions may also offer short learning programmes of a non[formal nature. The nature of non[ormal training in LIS education is closely related to the in \$ervice training offered by library staff and could relieve library staff of constraints imposed by time and staff shortages.

Although tertiary institutions can, to a certain extent, benefit financially from offering such short learning programmes, only a certificate of attendance may be issued on completion, since short learning programmes are not formal learning programmes.

\subsection{Distance learning institutions and LIS curricula}

Distance learning ${ }^{4}$ is another way of offering learning programmes that may provide in the training needs of general library workers. Distance learning institutions offer training to students who cannot - for whatever reason - attend learning programmes at a contact university. Distance learning opportunities are especially advantageous to people who are already working and who wish to improve their academic profile without leaving their workplace to attend classes.

Prior to 2004 there were only two LIS schools in South Africa that offered LIS training through distance learning, namely Unisa and Technikon SA. The latter was the country's only distance learning technikon (Van Rensburg 2008).

As a tertiary learning institution, Unisa used to offer only formal training programmes that complied with the requirements of the SAQA, as described in the HEQF of the Council for Higher Education (Department of Education 2007). An advantage of distance learning to LIS education is that learning programmes of the same standard can be offered to LIS practitioners countrywide.

As indicated earlier the LIS training programmes offered by TSA had a strong vocational component, while the LIS training programmes offered through Unisa were, and still are, more theoretical in their approach. Both learning institutions offered diplomas and bachelor's degrees at undergraduate level. TSA offered a National Certificate in Library and Information Studies (NCLIS), which was an exit level of their National Diploma in Library and Information Studies (NDLIS). The NCLIS is explicitly mentioned here because it was the only distance learning programme aimed at meeting the needs of general library workers.

\section{Challenges facing LIS educators}

The cost of offering a particular qualification at a tertiary learning institution is a decisive factor, which requires a minimum number of students per cost unit, as stipulated by the internally accepted HEMIS of the respective tertiary institution, (e.g. for Unisa the minimum numbers of students per undergraduate level are 100 students per first level module, 50 per second level module, and 20 per third level module). As modules in a learning programme are viewed as cost units, the minimum number of students required per module at the different year levels of a learning programme has serious implications for the variety of programmes that can be offered by LIS educators. Unless the respective modules

4. Distance learning is interpreted here as educational instruction where lecturers and students are separated by time and/or space (Moore \&Thompson 1990). 
reflect the minimum number of students the learning programme is in danger of no longer being subsidised and may eventually be closed down.

In addition, amendments to the Higher Education Act IOI of 1997 (Department of Education 2007) no longer allows for sharing of first and second level modules among different learning programmes such as diplomas and degrees. This had grave implications for LIS qualifications that originated prior to the amendments of the Higher Education Act I0I of 1997.

Between 2000 and 2006 the number of tertiary institutions in South Africa offering LIS education and training programmes were reduced from 18 to 12 (DAC 2009).

\subsection{LIS programmes at Unisa before the merger}

From the above discussion on legislation it should be clear that legislation provides a framework in which LIS education can be offered to satisfy the needs of the LIS industry. How LIS education manifests itself at tertiary institutions depends largely on the criteria associated with standards such as those set by the standard generation body (SGB) of the Council of Higher Education and issues such as cost accounting that determine the viability of learning programmes within a particular learning institution. In addition changes in the higher educational environment can also pose challenges and affect the parameters in which LIS education can be offered. The discussion that follows demonstrates how various factors can affect LIS education in a real life situation. The discussion will show primarily how Unisa and the TSA as distance learning institutions complied with requirements of legislation by offering a variety of learning programmes before and after the merger. Offering a variety of learning programmes was intended to provide in the need for appropriately qualified professional as well as support staff in libraries.

Before the merger with TSA, Unisa could cope with the challenges presented by the LIS industry and the CHE by offering a four[year bachelor's degree in applied information science (known as the Blnf degree) and a two year diploma in information science. This diploma shared modules with the BInf degree up to the second year level. In addition, Unisa also offered a diploma in library services for children and youth, which also shared some of the modules with the Blnf degree. In this way Unisa could satisfy the needs of both library professionals and paraprofessionals. However, these learning programmes did not cater for training of general library workers (usually a certificate course), as university learning programmes started training at NQF level 5.

Prior to the merger technikons could offer training programmes that complied with the requirements of vocational training and could offer modules in their learning programmes with NQF levels lower than level 5. As such, technikons were better placed to offer certificate courses of one year's duration to satisfy the training needs of general library workers. Thus, similar to Unisa, the technikons coped with the demands of LIS and CHE by providing different exit levels for students: a national certificate course after one year's study, a national diploma after three years' study, or a technical bachelor's degree in Library and Information Studies - the BTLIS - after four years' study. Technikon learning programmes were more practical and better satisfied the demand for vocational training.

In both cases module sharing among learning programmes was a mechanism to cope with the set criteria for the minimum number of students per module required to remain financially viable, since both programmes contained modules that would not have been able to meet the minimum criteria.

\subsection{LIS programmes at Unisa after the merger}

The restructuring of higher education in South Africa affected LIS training in unexpected ways. Institutions affected by the merger had to redesign their educational offerings. This inevitably led to a reduction in the number of qualifications offered (DAC 2010:xv). In addition, advances in information technology and changes in the workforce - with implications for libraries - required adjustments in their approach to LIS training. The merger between the old Unisa and former TSA resulted in the new Unisa ending up with two LIS degree qualifications that were almost similar in content. This situation is depicted in table $\mathrm{I}$.

A major challenge that faced the Department of Information Science at Unisa (hereafter the Department) was that the one degree was more theoretical and the other one more practical in nature. In addition, the composition of the degree with the vocational (more practical) component meant that it could accommodate the training of general library workers, while the entry levels for learning programmes at universities did not provide for training at an entry level acceptable to general library workers.

In both programmes there were modules that did not attract adequate enrolment to justify maintaining both in terms of cost units. One option was the conflation of the two programmes in order to secure enough registrations and also to ensure the correct NQF levels of the respective modules in the programme. Although this situation was not unique to Unisa it sheds light on the challenges that faced tertiary learning institutions with regard to LIS education after merging.

SA Jnl Libs \& Info Sci 2010, 76(I) 
Table I LIS qualifications at Unisa after 2006

\begin{tabular}{|l|l|l|l|l|l|l|l|l|}
\hline \multicolumn{2}{|l|}{ Former TSA qualifications } & \multicolumn{2}{l|}{ Unisa (old curriculum) } \\
\hline Qualification & Credits & NQF & Duration & Qualification & \multicolumn{2}{l|}{ Credits } & NQF & Duration \\
\hline National Certificate & 120 & 5 & I year & \multicolumn{3}{l|}{} \\
\hline National Higher Cert. & 240 & 5 & 2 years & Dipl. Inform. Science & 240 & 5 & 2 years \\
\hline Nat. Diploma (NDLIS) & 360 & 6 & 3 years & Dipl. in Inform. Services for Children \& Youth & 240 & 5 & 2 years \\
\hline Bacc Technol. (BTLIS) & 480 & 7 & $\begin{array}{l}4 \text { years } \\
\text { (cumulat.) }\end{array}$ & Bachelor of Info. Science & 480 & 7 & $\begin{array}{l}4 \text { years } \\
\text { (Discontin. 2007) }\end{array}$ \\
\hline & & & & Bachelor of Info. Science & 360 & 6 & $\begin{array}{l}3 \text { years } \\
\text { (Introduced 2008) }\end{array}$ \\
\hline
\end{tabular}

Since it was not possible to offer two qualifications with similar content, credits and NQF levels, the Department had no alternative but to conflate the contents of both programmes into one three_year Blnf degree to derive maximum benefit from both qualifications and simultaneously comply with the criteria of a minimum number of students per module (Department of Information Science 2007).

Earning subsidies through varying types and levels of training programme was another factor that contributed to the decision to conflate the two four[year degrees into one three[year bachelor's degree. For example, the Department could earn more subsidies with a three[year degree followed by an honours programme than with a four|year degree without an honours programme, but with a coursework master's programme as was the case with the former TSA package. Thus it was also a "bread and butter issue" for the Department, irrespective of the LIS industry. However, in the long run, the LIS industry apparently has been affected negatively by this arrangement as explained hereafter.

Although this situation seemed to have provided a solution for the LIS educator, the merger had a knock[on effect in the LIS industry. Firstly, library and information services lost out on the delivery of trained library workers with hands $5 n$ experience offered by a vocational training programme. Secondly, the LIS industry was confronted with three[year and four[year bachelor's degree candidates who were competing for the same post levels in the workplace.

In terms of general library workers and paraprofessional staff, the merger also caused problems. The former technikons - including TSA - were the only learning institutions that offered certificate programmes suitable for general library workers. With the new dispensation the practice of having exit levels in learning programmes were abandoned. (The certificate courses offered by technikons used to constitute the first exit level of their learning programmes.) In addition diplomas now carried the same number of credits as the new three Yyear BInf degree. It was therefore not viable for the Department to introduce another diploma programme that competed for the same credits and could cause further confusion in the workplace.

\subsection{Model sharing between learning programmes}

In addition to the conflation of the two degree programmes, the Department had also offered two diplomas, namely the Diploma in Information Science and the Diploma in Information Services for Children and Youth. As mentioned before, both these diplomas had shared first $\square$ and second level modules with the Blnf degree. According to the programme qualification mix (PQM) required by the HEQF a qualification may not share more than $50 \%$ of its modules with another qualification (Department of Education 2007). The Department, therefore, had no choice but to request, that the current Diploma in Information Science be recurriculated and aligned with the HEQF requirements, and that the Diploma in Information Services for Children and Youth be discontinued (College of Human Sciences 2007). This change in requirements has meant substantial loss of students for the Department, to the extent that the minimum numbers required for first Пevel registrations for the BInf degree may be jeopardised.

The conflation of the two degrees and discontinuation of diplomas brought about additional challenges. The Department entered a drawn but period of phasing out old curricula and phasing in the new curriculum. Since 2007 the Department has been in the unenviable position of running old and new modules concurrently, with a reduced number of permanent academic staff. Owing to the low number of staff points vacancies were filled with contract personnel, which has brought about problems of its own.

After the word spread that the BTech qualifications of the former TSA would be phased out, the Department has received numerous enquiries from both employers and prospective students who were interested in vocational courses, such as certificate courses, with a shorter duration than the existing diplomas and degrees. In addition, one concern of the Department was whether to retain or discard the study material of the phased \ut national certificate (NCLIS), without knowing how extensive the real need was for the delivery of 'work ready' library workers. This concern was instrumental 
in the investigation into the need for a learning programme for general library workers (Meyer 2009). In the meantime dissatisfaction grew within the LIS industry, which faced dwindling numbers of old hands in terms of support staff and the appointment of untrained general workers, as well as a new group of jobseekers unfamiliar with the working culture of a library (Meyer 2009).

\section{Addressing the challenges}

Despite the downside to LIS education and training caused by the merger and institutional demands, amendments to the HEQF, offered a window of opportunity (Department of Education 2007:II). These amendments allowed tertiary learning institutions to develop curricula for vocational training at Higher Certificate, and Advanced Certificate level. This implied that Unisa as tertiary learning institution could now offer a formal learning programme to satisfy the needs of general library workers. The advantages to Unisa of offering a certificate programme include following:

- The core content of the former TSA's national certificate programme is still available and can be updated and integrated into a higher certificate or advanced certificate programme.

- The options offered through the new certificate programmes are more inclined to vocational training, which will be more appealing to general library workers who perform primarily task trelated jobs.

- Although certificate programmes - being at the lower level of formal learning programmes identified by HEQF - carry fewer credits than any of the other qualifications, they do allow for an access route to a higher level learning programme as indicated in figure I.

- The outcomes of the recent survey of the Department (Meyer 2009) proved that there is a high demand (62\%) for trained general library workers. This can be interpreted that there might be a continuous demand for training at certificate level in future. This in turn implies that an increase in student numbers may avert the danger of too few registrations per module that may result in the discontinuation of a learning programme.

- In addition, Unisa has at its disposal the services of the Directorate: Curriculum and Learning Development (DCLD), which can be approached to assist the Department in developing the content for a workbased learning programme suitable for general library workers.

- Since Unisa is a distance learning institution, the Department can offer a standardised learning programme countrywide to general library workers in the LIS industry.

Despite the advantages indicated here, there are also new challenges that may prevent the immediate introduction of an appropriate certificate programme for general library workers. For example:

- It will take a minimum of two years for the Department to apply for accreditation to introduce a new programme. This will cause a gap in the delivery of 'work ready' library workers, since the last of the former TSA learning programmes will be phased out by 2010.

- Current staff points and workloads in the Department do not allow for the development of enough modules to populate a certificate programme.

- Vocational training implies WIL, which in itself can be an arduous task and needs to be carefully negotiated with the LIS industry concerning the logistics around it.

4.1 The short learning programme option

As indicated earlier, tertiary institutions may also offer short learning programmes of a non formal nature, from which the educators would benefit financially. Although a tertiary institution may benefit financially from offering such short learning programmes, a disadvantage to the student could be that only a certificate of attendance can be issued on completion. This is because short learning programmes are not formal learning programmes. Non formal learning programmes are normally not subsidised by government (that is, DHET), and are also not necessarily acknowledged for promotion purposes in the LIS industry.

To address these new challenges in the interim, the Department considers offering a short learning programme for general library workers, through the Centre for Applied Communication (CAC). The Centre has recently been incorporated into the Department of Information Science (Rodrigues 2009). Although CAC is established within the Department, it operates independently in the sense that it has its own infrastructure, administrative support and budget.

The short learning programmes offered through CAC are normally non formal, non\$ubsidy [earning programmes, which mean they are not SAQA faccredited. This implies that they:

- do not provide an access route to formal qualifications;

- do not count for promotion purposes;

- may or may not be credit bearing; and

- do not qualify for a subsidy from the Department of Education.

However, the advantages are that:

- non formal, task related training can be offered to staff already appointed in the LIS industry;

- CAC programmes focus on specific issues or skills demands of individual clients;

SA JnI Libs \& Info Sci 2010, 76(I) 
- learning programmes will be primarily practical in nature, with hands $[$ on exercises and less focus on theoretical content;

- students can be trained at a venue close to their workplace; and

- training can take various forms, from one day workshops to short learning programmes of one-year duration Rodrigues (2009) observed that perhaps the most important advantage of nonโformal training programmes offered by CAC is that they can serve as an incubator for formal offerings in future.

\section{Summary and conclusion}

This discussion pointed out that the task[related nature of the work performed by general library workers and the associated entry level criteria require a different type of learning programme than the conventional learning programmes for professionally qualified library staff. The particular learning requirements of this staff component of LIS, the parameters set by the HEQF, as well as prerequisites for cost units set by the respective learning institutions to balance their books pose challenges to LIS educators that require fine footwork to satisfy both sides and still make ends meet.

The discussion also demonstrated that decision making processes often have unforeseen knock bn effects that cause serious problems for the different stakeholders. The LIS industry is often unaware of how LIS educators are affected by changes to legislation; LIS educators, in turn, are often ignorant of how the LIS industry is affected by the many qualifications they encounter resulting from changes in learning programmes that are made to serve the purposes of LIS educators.

The discussion further showed that amendments to the Higher Education Act introduced greater flexibility with regard to the development of vocational training programmes at university level. However, current programme contents need to be revisited to cover aspects that came to light during the survey conducted for the Department (Meyer 2009). More attention should be given to closer cooperation between LIS and the LIS educators to address the need for vocational training of general library workers.

The incorporation of the CAC into the Department serves as an interim measure that allows Unisa to offer short learning programmes to general library workers countrywide, while the viability of a suitable formal learning programme for general library workers needs to be negotiated among LIS educators, library associations and the LIS industry.

Hopefully the illumination of the challenges facing LIS education will bring greater awareness among all stakeholders and will contribute to a concerted effort to find appropriate solutions to the training needs of general library workers in the near future.

\section{References}

Ashcroft, L. 2004. Developing competencies, critical analysis and personal transferable skills in future information professionals. Library Review, 53(2):82 88.

Biddiscombe, R. 200I. The development of information professionals' needs for internet and IT skills: experiences at the University of Birmingham. Program: Electronic Library and Information Systems, 35(2):157】66.

Blankson_Hermans, L. \& Hibberd, B.J. 2004. An assessment of LIS curricula and the field of practice in the commercial sector. New Library World, 105(I 202/I203): 269[280.

Brown, C. 2007. Request from Ekurhuleni Metropolitan Library and Information Services regarding an information training supplier (e Tmail enquiry received 9 November 2007).

City of Johannesburg. Library and Information Services. 2008. Job description form for general library workers/assistants.

College of Human Sciences. See University of South Africa College of Human Sciences.

Department of Arts and Culture. June 2007. Legal and accountability framework. Online]. http://www.dac.gov.za/projects/nclis/ DAC public library funding report.pdf. 19 June 2009.

Department of Arts and Culture (DAC) and National Council for Library and Information Services (NCLIS). July 2009. The library and information services (LIS) transformation charter. Online]. http://www.dac.gov.za/publications/reports/2009/ Transformation Charter.pdf. Accessed 10 March 2010.

Department of Education. 2007. The Higher Education Qualifications Framework: Higher Education Act, 1997 (Act no. $10 \mathrm{I}$ of 1997). Pretoria: Government Printer.

Dept. of Information Science See University of South Africa. Department of Information Science

Dominy, G. 2003. The conundrum of community libraries in provinces. Cape Librarian, 47(I):40[4I .

Ekurhuleni Metropolitan Library and Information Services. 2008. Job description form for benchmarked positions: Library assistant.

Fisher, B. 2004. Workforce skills development: the professional imperative for information services in the United Kingdom. Australian Library and Information Association [ALIA) Biennial Conference, 2I-24 September, Gold Coast. [Online]. http:// conference.alia.org.au/alia2004/pdfs/fisher.b.paper.pdf. Accessed I 4 June 2009.

Gerolimos, M. 2009. Skills developed through library and information science. Library Review, 58(7):527[540.

Havenga, P. 2007. Higher Education Qualifications Framework (PowerPoint presentation). Pretoria: Unisa.

LIASA. 2008. Subsidized professional training to start 10 April (E[mail to author)

Luo, L. 2007. Chat reference competencies: identification from literature review and librarian interviews. Reference Services Review, 35(2): 195[209. 
Meyer, H.W.J. 2009. The introduction of a vocational training programme for library workers in public and related libraries: a feasibility study (Department of Information Science (internal report)).

Middleton, M. 2003. Skills expectations of library graduates. New Library World, I04(I I 84/ I 85 ):42[56.

Minishi Majanja, M.K. 2009. Which way for LIS education and training in South Africa? Some considerations from contact and distance learning, in: Proceedings of DLIS $10^{\text {th }}$ Annual Conference, University of Zululand, I0- I I September 2009. Editors: D.N. Ocholla \& D. Jacobs. KwaDlangwezwa: University of Zululand: I 7[B4.

Minishi Majanja, M.K. \& Ocholla, D.N. 2004. Auditing information communication technologies in library and information science education in Africa. Education for Information, 22: I87[22I.

Moore, M.G. and Thompson, M. 1990. The effects of distance learning: A summary of literature. University Park, Pa: American Center for the Study of Distance Education.

Musiker, R. 1986. Companion to South African Libraries. Johannesburg: Ad Donker.

Ocholla, D. and Bothma, T. 2007. Library and information education and training in South Africa, in: Libraries for the future: Progress and development of South African libraries, 73 ${ }^{\text {rd }}$ IFLA General Conference and Council, 19-23 August 2007, Durban, South Africa. Editors: T.Bothma, P.Underwood \& P.Ngulube. Pretoria: LIASA:|49】68.

Pretorius, K. 2007. Request from South African police services to introduce general library workers to basic reference work and customer services (E†mail 10 October 2006, Pretoria)

RSG. Praat saam. [talk programme] I 8 July 2008.

Rodrigues, A. 2009. Short learning programmes and the Centre for Applied Communication, presented at Student Symposium of Unisa, Department of Information Science, I 2 June 2009.

South African Community Library and Information Services Bill. 20 I0. http://www.dac.gov.za/bills.htm

Tshwane Community Library Services. 2008. Job description form for general library workers.

University of South Africa. Department of Information Science. 2007. Academic audit (internal report).

University of South Africa. College of Human Sciences. Committee. 2007. Meeting held on 4 September 2007. (internal report).

Van Aswegen, J. 2006. Request from Ekurhuleni Metropolitan Library and Information Services to introduce their general library workers to basic reference services (E[mail and telephonic discussions, January and May 2006)

Van Rensburg, E. 2008. Evaluating workbased learning: insights from an illuminative evaluation study of work based learning in a vocational qualification. Industry \& Higher Education, 22(4): I 10. 